\title{
PENGARUH CURRENT RATIO DAN RETURN ON ASSET (ROA) TERHADAP OPINI AUDIT GOING CONCERN PERUSAHAAN PELAYARAN YANG GO PUBLIC PERIODE 2012 - 2016
}

\author{
Indriyani, SE, M.Si \\ Program Studi KPN \\ Akademi Maritim Nusantara \\ Email : indrip2cd11010@gmail.com \\ Tiara Pandansari, SE, Ak, M.Si., CA \\ Fakultas Ekonomi dan Bisnis \\ Universitas Muhammadiyah Purwokerto \\ Email : tiarapandansari@gmail.com
}

\begin{abstract}
ABSTRAK
Penelitian ini memiliki tujuan mengetahui pengaruh current ratio dan $R O A$ terhadap opini audit going concern. Objek dari penelitian ini adalah perusahaan pelayaran yang go public. Penelitian ini merupakan penelitian kuantitatif dengan mengambil sampel sebanyak 12 perusahaan pelayaran selama 5 tahun (2012-2016), sehingga data yang dianalisis sebanyak 60 data. Analisis data menggunakan regresi logistik. Penelitian ini menunjukkan bahwa $C R$ berpengaruh terhadap opini audit going concern, dan ROA tidak berpengaruh terhadap opini audit going concern.
\end{abstract}

Kata Kunci : Current Ratio, Return On Asset, going concern

\begin{abstract}
This study aims to determine the effect of current ratio and ROA on going-concern audit opinion. The object of this research is shipping companies that go public. this research is a quantitative research by taking a sample of 12 shipping companies for 5 years (2012-2016), so that the data analyzed were 60 pieces. Data analysis using logistic regression. This study shows that $C R$ affects the going concern audit opinion, and ROA does not affect the going-concern audit opinion.
\end{abstract}

Keywords: liquidity, profitability, going concern

\section{PENDAHULUAN}

Perusahaan pelayaran saat ini memiliki peran yang penting di Indonesia karena sebagian besar negara Indonesia terdiri atas laut. Setiap perusahaan diharuskan mampu menjaga kelangsungan usaha (going concern) di era globalisasi. Menurut Standar Akuntansi Keuangan (IAI, 2009:5) "going concern merupakan asumsi dasar dalam penyusunan laporan keuangan dimana suatu perusahaan tidak memiliki rmaksud atau memiliki keinginan untuk dilikuidasi atau dikurangi secara material skala usahanya." Perusahaan mempertahankan kelangsungan hidupnya dengan memperhatikan kinerjanya yang dapat diukur melalui rasio keuangan. Menurut Kosasih dan Hananto (2007) Analisis rasio perusahaan dalam analisis keuangan memperlihatkan hubungan antara perkiraan laporan keuangan.

Van Horne dan Machowicz dalam Mansur K (2015) menyatakan bahwa likuiditas dan kemampuan memperoleh laba berbanding terbalik, sehingga apabila perusahaan menetapkan aset yang besar maka likuiditas aman, tetapi harapan mendapatkan laba yang besar menjadi turun. Tingginya likuiditas tidak selalu memberi keuntungan perusahaan karena adanya peluang memiliki 
dana menganggur dalam investasi pada proyek yang menguntungkan perusahaan. Selain menggunakan rasio keuangan, perusahaan juga melakukan audit terhadap laporan keuangan. Setelah melakukan audit, auditor memberikan opini. Menurut Ashton dalam Widyantari (2011) dalam Febriana dan Sofianti (2016) menyatakan bahawa waktu audit dengan opini going concern lebih lama.

Penelitian yang berkaitan dengan penggunaan rasio likuiditas, rasio profitablilitas, dan opini going concern dilakukan oleh Sormunen dan Laitinen (2012) Sinurat, FK (2015), Setiawan, F (2015) membuktikan bahwa rasio likuiditas memiliki pengaruh pada opini audit going concern. Sedangkan berkaitan dengan profitabilitas dan going concern dilakukan oleh Hani dkk (2003), Setiawan, F (2015), Pradika (2017) menyatakan bahwa profitabilitas berpengaruh signifikan terhadap opini audit going concern. Hasil sebaliknya ditunjukkan oleh Christian Lie,dkk (2016). Hasil penelitian yang berbeda menimbulkan ketertarikan untuk diteliti. Sektor trasnportasi, terutama transportasi laut saat ini sangat diperhatikan kinerjanya berkaitan dengan pembangunan saat ini yang mengedepankan sektor maritim. Adapun tujuan yang akan dicapai dalam kajian ini adalah 1) melakukan analisis pengaruh Current Ratio berpengaruh terhadap opini audit going concern Perusahaan Pelayaran yang Go Public Periode 2012 - 2016, 2) melakukan analisis pengaruh $R O A$ berpengaruh terhadap opini audit going concern Perusahaan Pelayaran yang Go Public Periode 2012 - 2016

\section{TINJAUAN PUSTAKA}

\section{Teori Agensi}

Menurut Jensen dan Meckling (1976) dalam Jayanti, Dwi (2014) menyatakan bahwa "Shareholder atau prinsipal memberikan delegasi pada manajer dalam membuat keputusan, karena tindakan agen tidak selalu sesuai dengan keinginan prinsipal dalam pengelolaan keuangan maka membutuhkan pihak ketiga dalam hal ini auditor."

\section{Rasio Keuangan}

Penelitian ini menggunakan :

1. Rasio Likuiditas

Rasio likuiditas yang digunakan adalah

$$
\text { Current Ratio = }
$$

2. Rasio Profitabilitas

Hutang Lancar

Rasio Profitabilitas menggunakan :

$$
R O A=\frac{\text { Laba atau Rugi Bersih }}{\text { Total Asset }}
$$

\section{OPINI AUDIT GOING CONCERN}

Menurut SPAP ( 2011 ) Opini Audit Going Concern merupakan opini audit berkaitan dengan kemampuan perusahaaan untuk mempertahankan kelangsungan hidupnya.

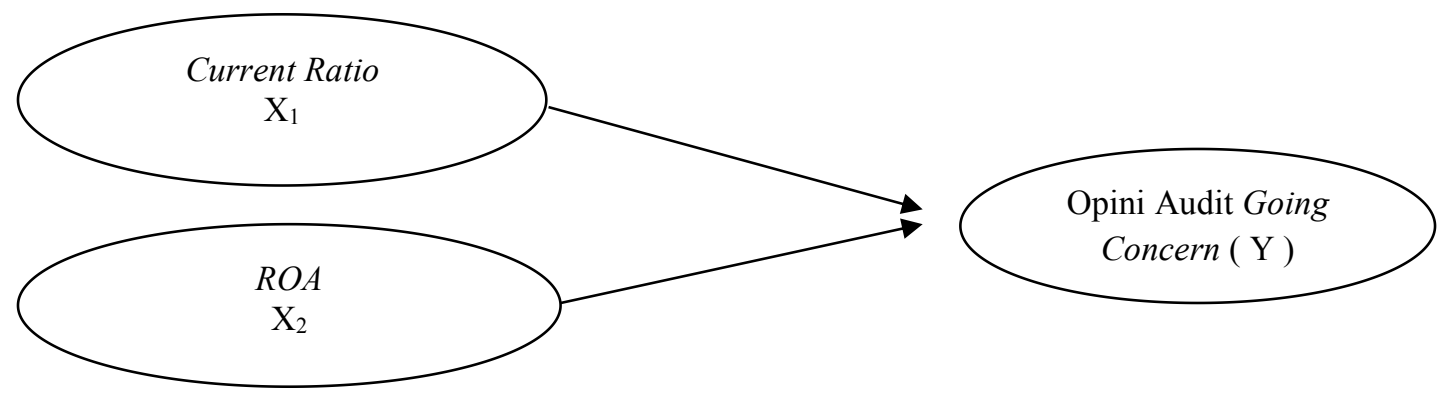

Gambar 1. Kerangka Pemikiran 


\section{HIPOTESIS}

Penelitian terdahulu

Penelitian Hani, dkk (2003), Sormunen dan Laitinen (2012), Sinurat, FK (2015), Setiawan, F (2015) menyatakan bahwa rasio likuiditas berpengaruh terhadap auditor dalam memberikan opini audit going concern.

H1 : Rasio Likuiditas yang diukur dengan current ratio berpengaruh terhadap opini audit going concern.

Hani, dkk (2003) Setiawan, F (2015) dan Pradika (2017) menyatakan bahwa rasio profitabilitas berpengaruh terhadap opini audit going concern.

$\mathrm{H} 2$ : Rasio Profitabilitas yang diukur dengan $R O A$ berpengaruh terhadap opini audit going concern

\section{METODE PENELITIAN}

1. Jenis Penelitian

Penelitian ini merupakan jenis penelitian kuantitatif dengan menggunakan data historis berupa angka-angka yang dianalisis statistik (Sugiyono, 2015).

2. Lokasi dan obyek penelitian

Penelitian ini menggunakan data sekunder yang diperoleh dari www.idx.co.id dengan melihat laporan keuangan perusahaan pelayaran yang go public sebanyak 12 perusahaan di tahun 2012, tahun 2013, tahun 2014, tahun 2015, dan tahun 2016.

3. Populasi dan Sampel

Penelitian ini memiliki populasi yaitu perusahaan pelayaran yang menerbitkan laporan keuangannya diaudit dan dipublikasikan selama tahun 2012-2016. Data penelitian diambil dengan metode purposive sampling dengan mengambil sample dengan kriteria-kriteria yang ditentukan. Menurut Jogiyanto (2008:122). Teknik purposive sampling mendasarkan ciri-ciri atau sifat-sifat tertentu yang dianggap memiliki ikatan erat dengan ciri-ciri atau sifat-sifat dalam populasi yang sudah diketahui sebelumnya.

4. Metode Pengumpulan Data

Data sekunder dalam penelitian ini dikumpulkan menggunakan metode dokumentasi dengan mencari dan memilih data yang dihasilkan oleh website Bursa Efek Indonesia.

5. Metode Pengolahan Data

Data diolah menggunakan analisis statistik deskriptif. Menurut Arikunto (2010: 3) metode deskriptif memiliki tujuan melakukan penyelidikian terhadap keadaan, kondisi atau hal lain yang telah disebutkan, dan memiliki hasil pemaparan dalam laporan penelitian.

\section{TEKNIK ANALISIS DATA}

\section{Analisis Data}

Penelitian ini melakukan analisis dan pengujian dengan menggunakan uji statistik deskriptif dan statistik inferensial dalam menguji hipótesisnya.

1. Analisis Statistik Deskriptif

Pengujian statistik desktiptif digunakan untuk untuk menggambarkan variabel-variabel dalam penelitian ini. Statistik deskriptif yang digunakan adalah mean, nilai minimum dan maksimum.

2. Analisis Statistik Inferensial

Analisis statistik inferensial digunakan untuk menguji hipotesis yang diajukan. Model regresi logistik digunakan untuk menguji hipotesis. Menurut Ghozali (2011), regresi logistik merupakan regresi untuk menguji apakah variabel bebas dapat memprediksi probabilitas terjadinya variabel terikat.

Regresi logistik tidak memiliki asumsi normalitas sehingga tidak harus memiliki distribusi normal, linear maupun memiliki varian yang sama dalam setiap grup. Gujarati (2003) menyatakan bahwa regresi logistik mengabaikan heteroskedastisitas.

Adapun rumus dalam penelitian ini adalah:

$$
\mathrm{L} n \frac{\mathrm{GC}}{1-\mathrm{GC}}=\alpha+\beta 1 \mathrm{CR}+\beta 2 \mathrm{ROA}+\varepsilon
$$


Keterangan :

$\mathrm{L} n \frac{\mathrm{GC}}{\mathbf{1 - G C}}=$ Opini going concern yang diproksikan dengan variabel dummy

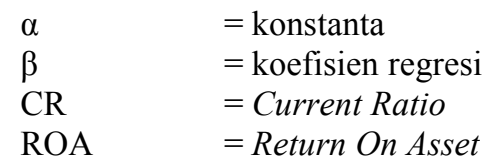

Likuiditas menggunakan Current Ratio (CR) dengan rumus aktiva lancar dibagi hutang lancar. Profitabilitas menggunakan Return On Asset (ROA) dengan rumus laba bersih dibagi total aktiva. Opini going concern diukur dengan variabel dummy, dengan pemberian kode 1 jika mendapat opini going concern dan kode 0 jika tidak mendapatkan opini going concern. Hal pertama yang dilakukan adalah uji overall model fit untuk melihat penggunaan model regresi logistik fit atau cocok dengan data yang digunakan.

3. Pengujian Hipotesis

Tahapan pengujian hipotesis sebagai berikut:

a.Melakukan penilaian Model Fit dan Keseluruhan Model (Overall model Fit)

b.Melakukan penilaian kelayakan Model Regresi

c. Koefisien Determinasi

d.Matrik Klasifikasi

e.Menguji Koefisien Regresi

\section{HASIL DAN PEMBAHASAN}

Analisis Statistik Deskriptif

Tabel 1. Statistik Deskriptif

\begin{tabular}{lrrrcr}
\hline & N & Minimum & Maximum & Mean & Std. Deviation \\
\hline Current Ratio & 60 & 0.0350 & 4.5328 & 1.015088 & 0.8287060 \\
\hline Return on Asset & 60 & -0.6899 & 1.8517 & 0.015725 & 0.2796064 \\
\hline Valid N & 60 & & & & \\
\hline
\end{tabular}

Hasil statitik deskriptif menunjukkan current ratio mempunyai nilai maksimum 4.5328 dan nilai minimum 0.0350 dan mean sebesar 1.015088 dengan standar deviasi 0.8287060 , karena mean lebih besar dari standar deviasi maka data yang dihasilkan terdistribusi normal. Sedangkan return on asset memiliki nilai maksimum 1.8517 dan nilai minimum -0.6899 dengan mean yang dimiliki sebesar 0.015725 dan standar deviasi 0.2796064 . Mean yang dihasilkan lebih kecil dari standar deviasi sehingga data tidak terdistribusi normal.

\section{Frekuensi Going Concern}

Tabel 2

Frekuensi Going Concern

\begin{tabular}{llrr}
\hline & & Frequency & Valid Percent \\
\hline \multirow{3}{*}{ Valid } & Non Going Concern & 42 & 70 \\
\cline { 2 - 4 } & Going Concern & 18 & 30 \\
\cline { 2 - 4 } & Total & 60 & 100 \\
\hline
\end{tabular}

Berdasarkan hasil frekuensi going concern ditunjukkan bahwa 42 perusahaan tidak diberi opini going concern dengan presentase $70 \%$. Sedangkan perusahaaan dengan opini going concern sebanyak 18 dengan presentase $30 \%$. 


\section{Menilai Model Fit dan Keseluruhan Model}

Tabel 3

Hosmer and Lemeshow Test

\begin{tabular}{lrrr}
\hline Step & Chi-square & Df & \multicolumn{1}{c}{ Sig. } \\
\hline 1 & 2.957 & 8 & 0.937 \\
\hline
\end{tabular}

Berdasarkan hasil uji hosmer dan lemeshow, nilai chi square sebesar 2.957 dan nilai signifikansi $0.937>0.05$ artinya model yang dihipotesiskan fit dan layak.

\section{Menilai Kelayakan Model Regresi}

Tabel 4

Block Number 0

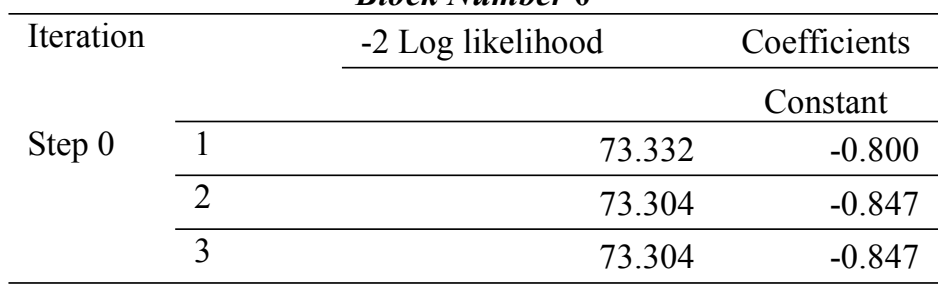

Hasil perhitungan nilai -2Loglikelihood pada block number 0 memiliki nilai sebesar 73.332.

Tabel

Block Number 1

\begin{tabular}{llrrrr}
\hline & & & \multicolumn{3}{c}{ Coefficients } \\
\cline { 4 - 6 } Iteration & & -2 Log likelihood & Constant & CR & \multicolumn{1}{c}{ ROA } \\
\hline Step 1 & 1 & 64.013 & 0.039 & -0.821 & -0.372 \\
\cline { 2 - 6 } & 2 & 60.335 & 0.565 & -1.633 & -0.359 \\
\cline { 2 - 6 } & 3 & 59.710 & 0.853 & -2.123 & -0.288 \\
\cline { 2 - 6 } & 4 & 59.692 & 0.903 & -2.218 & -0.270 \\
\cline { 2 - 6 } & 5 & 59.692 & 0.905 & -2.221 & -0.269 \\
\cline { 2 - 6 } & 6 & 59.692 & 0.905 & -2.221 & -0.269 \\
\hline
\end{tabular}

Perhitungan nilai -2Loglikelihood pada block number 1 atau model dengan konstan dan variabel bebas mengalami penurunan dibandingkan block number 0 yaitu 59.692. Keseluruhan penilaian dalam model regresi digunakan nilai -2Loglikelihood, apabila penurunan terjadi dari block number 0 ke block number 1 maka model block number 1 menjadi lebih baik.

\section{Koefisien Determinasi}

Tabel 6

Nagelkerke R Square

\begin{tabular}{lrrr}
\hline Step & -2 Log likelihood & Cox \& Snell R Square & Nagelkerke R Square \\
\hline 1 & 59.692 & 0.203 & 0.288 \\
\hline
\end{tabular}

Nilai nagelkerke r square menunjukkan pengujian koefisein determinasi yang memiliki nilai 0.288 atau $28.8 \%$. Hasil tersebut menjelaskan bahwa variabel $\mathrm{x}$ berpengaruh variable y sebesar $28.8 \%$ dan pengaruh faktor lainnya sebesar $71.2 \%$. 
Matrik Klasifikasi

Tabel 7

Ketepatan Prediksi Klasifikasi

\begin{tabular}{lllccc}
\hline & & \multicolumn{3}{c}{ Predicted } \\
\cline { 3 - 5 } & & & \multicolumn{2}{c}{ Going Concern } & \\
\cline { 3 - 5 } Observed & & & Going & Percentage \\
\cline { 3 - 5 } & & & Non Going Concern & Concern & Correct \\
\hline Step 1 & Going Concern & Non Going Concern & 38 & 4 & 90.5 \\
\cline { 3 - 6 } & & Going Concern & 9 & 9 & 50 \\
\cline { 3 - 6 } & Overall Percentage & & & 78.3 \\
\hline
\end{tabular}

Tabel ketepatan prediksi klasifikasi menujukkan 42 yang tidak diberikan opini going concern diprediksi oleh model 38 unit tidak diberi opini going concern dan 4 unit diberikan opini going concern. Oleh sebab itu memiliki nilai kebenaran klasifikasi 90.5\%. Sementara dari 18 unit observasi yang mengalami opini going concern diprediksi tepat oleh model 9 unit tidak diberi opini going concern dan 9 unit diberi opini audit going concern. Oleh sebab itu memiliki nilai kebenaran klasifikasi 50\%. Nilai overall percentage sebesar $78.3 \%$.

\section{Menguji Koefisien Regresi}

Tabel 8

Analisis Regresi Logistik

\begin{tabular}{|c|c|c|c|}
\hline \multirow{4}{*}{ Step 1} & & B & Sig. \\
\hline & CR & -2.221 & 0.005 \\
\hline & ROA & -0.269 & 0.829 \\
\hline & Constant & 0.905 & 0.142 \\
\hline
\end{tabular}

persamaan regresi logistik sebagai berikut:

$\operatorname{Ln}\left(\frac{G C I}{1-G C I}\right)=0.905-2.221 \mathrm{CR}-0.269 \mathrm{ROA}$

\section{Pengujian Hipotesis Pertama}

Hasil tabel analisis regresi logistik untuk current ratio memiliki nilai koefisien -2.221 dan signifikansi $0.005<0.05$ artinya likuiditas yang diukur menggunakan current ratio berpengaruh terhadap opini audit going concern, sehingga hipotesis pertama diterima. Likuditas yang tinggi atau rendah akan mempengaruhi perusahaan mendapatkan opini going concern. Perusahaan yang kurang likuid dan tidak dapat membayar kewajiban jangka pendek berpengaruh terhadap pemberian opini audit going concern (Hani dkk, 2003).

\section{Pengujian Hipotesis Kedua}

Berdasarkan tabel analisis regresi logistik return on asset memiliki nilai koefisein 0.269 dengan signifikansi $0.829>0.05$ artinya profitabilitas yang diukur dengan ROA tidak berpengaruh terhadap opini going concern. Hal ini menjelaskan bahwa hipotesis kedua ditolak. Tinggi atau rendahnya Return on asset uatu perusahaan tidak akan berpengaruh terhadap pemberian opini audit going concern. Hasil dari penelitian sesuai dengan penelitian Arma ( 2013 ) dan Putri ( 2018 ) yang menyatakan bahwa opini audit going concern tidak dipengaruhi oleh profitabilitas. 


\section{KESIMPULAN DAN SARAN}

\section{Kesimpulan}

Berdasarkan hasil analisis yang dibahas, maka kesimpulannya sebagai berikut :

1. Likuiditas yang diukur menggunakan $C R$ berpengaruh terhadap pemberian opini audit going concern pada perusahaan pelayaran yang go public periode $2012-2016$, hal ini ditunjukkan melalui nilai koefisien regresi $\mathrm{X}_{1}$ sebesar -2.221 dan nilai signifikansi yang lebih kecil dari 0,05 , sehingga tingginya rasio likuiditas menunjukkan semakin besarnya kemampuan perusahaan dalam memenuhi kewajiban jangka pendeknya, sehingga kemungkinan menerima opini audit going concern semakin kecil.

2. Profitabilitas yang diukur dengan $R O A$ tidak berpengaruh terhadap pemberian opini audit going concern pada perusahaan pelayaran yang yang go public periode 2012 - 2016, yang ditunjukkan dengan nilai koefisien regresi $\mathrm{X}_{2}$ sebesar 0,269 dan signifikansi lebih besar dari 0,05 sehingga profitabilitas tidak berpengaruh terhadap pemberian opini audit going concern sehingga auditor tidak melihat profitabilitas sebagai dasar dalam menerbitkan opini audit going concern

\section{Saran}

Peneliti selanjutnya dapat menambah jumlah perusahaan yang diteliti dan memperluas objek penelitian yang digunakan seperti objek perusahaan manufaktur dan perusahaan dagang.

\section{DAFTAR PUSTAKA}

Arma, Endra Ulkri. 2013. Pengaruh Profitabilitas, Likuiditas, dan Pertumbuhan Perusahaan Terhadap Penerimaan Opini Audit Going Concern(Studi Empiris Perusahaan Manufaktur yang Terdaftar di Bursa Efek Indonesia). Skripsi. Univesitas Negeri Padang, Padang.

Christian Lie, Rr. Puruwita Wardani, Toto Warsoko Pikir.2016. Pengaruh Likuiditas, Solvabilitas, Profitabilitas, dan Rencana Manajemen terhadap Opini Audit Going Concern (Studi Empiris Perusahaan Manufaktur di BEI) . Berkala Akuntansi dan Keuangan Indonesia, Vol. 1, No. 2 (2016): 84-105

Engkos Kosasih dan Hananto Soewedo. 2007. Manajemen Keuangan dan Akuntansi Perusahaan Pelayaran. Jakarta : Rajawali Pers.

Febriana, Doris dan Sofianti Dania, Septarina Prita. Analisis Pengaruh Rasio Likuiditas, Profitabilitas, Solvabilitas, Aktivitas dan Opini Audit Going Concern Tahun Sebelumnya Terhadap Opini Audit Going Concern. Jurnal Bisnis dan Manajemen Islam, Vol 4, No1 Juni 2016 hal 59 - hal 72

Setiawan,F.2015.Pengaruh Pertumbuhan Perusahaan, Profitabilitas,Likuiditas, dan Leverage Terhadap Opini AuditGoing Concern. Jurnal. Sekolah Tinggi Ilmu Ekonomi Indonesia (STIESIA).Surabaya.

Sinurat, F.K.2015. Analisis Pengaruh Likuiditas, Ukuran Perusahaan, dan Reputasi Audit Terhadap Penerimaan Opini AuditGoing Concern (Studi Empiris pada Perusahaan Manufaktur di Bursa Efek Indonesia Tahun 2011-2013). Skripsi. Universitas Sanata Dharma. Yogyakarta

Ghozali, Imam. 2009. Aplikasi Analisis Multivariate Dengan Program SPSS. Edisi Keempat. Semarang: Badan Penerbit Universitas Diponegoro.

Ghozali, Imam. 2011. Aplikasi Analisis Multivariate Dengan Program SPSS. Semarang: Badan Penerbit Universitas Diponegoro

Gujarati, Damodar. 2003. Ekonomimetrika Dasar, Erlangga, Jakarta 
Jurnal Manajemen dan Bisnis MEDIA EKONOMI, Vol . XIX No 1 Januari 2019

Hani, Cleary, Mukhlisin. 2003. Going Concern dan Opini Audit : Suatu Studi Pada Perusahaan Perbankkan di BEJ. Simposium Nasional Akuntansi VI. Surabaya.

Ikatan Akuntan Indonesia.2009. Standar Akuntansi Keuangan. Jakarta: Salemba Empat.

Ikatan Akuntan Indonesia. 2011. Standar Profesional Akuntan Publik (SPAP). Jakarta: Salemba Empat.

Jayanti, Dwi. Pengaruh Rasio Likuiditas dan Rasio Profitabilitas Terhadap Opini Audit Going Concern. Proccedings SNEB 2014. Hal. 1

Jogiyanto. 2008. Metodologi Penelitian Sistem Informasi. CV Andi Offset. Yogyakarta

Mansur, M.K.2015 Pengaruh Likuiditas Dan Solvabilitas Terhadap Profitabilitas . Skripsi. Universitas Islam Negeri Walisongo Semarang.

Pradika, Rizka Ardhi. 2017. Pengaruh Profitabilitas, Likuiditas, dan Ukuran Perusahaan Terhadap Opini Audit Going Concern : Studi pada Perusahaan Manufaktur yang Terdaftar di Bursa Efek Indonesia Tahun 2012-2015. Skripsi. Universitas Islam Negeri Syarif Hidayatullah

Putri, Bonita Riestianiko. 2018. Pengaruh Profitabilitas, Likuiditas, Solvabilitas, Pertumbuhan Perusahaan, dan Ukuran Perusahaan Terhadap Opini Audit Going Concern : Studi Empiris

pada Perusahaan Retail Trade yang terdaftar di Bursa Efek Indonesia Tahun 2012 - 2016. Skripsi. Universitas Islam Negeri Syarif Hidayatullah

Sormunen, Nina dan Teija Laitinen. 2012. Late Financial Distress Process Stages and Financial Ratio : Evidance for auditor's Going Concern Evaluation. Copenhagen Business School Sugiyono.2015. Metode Penelitian Kuantitatif Kualitatif R\&B. Bandung: Aflabeta.

www.idx.co.id. 